ORIGINAL ARTICLE

AFRICAN JOURNAL OF CLINICAL AND EXPERIMENTAL MICROBIOLOGY AJCEM/201076/21119

COPYRIGHT 2011

AFR. J. CLN. EXPER. MICROBIOL 12(3): 92-97
SEPTEMBER 2011 ISBN 1595-689X VOL 12(3)

-http://www ajolinfo/journals/ajcem

doi: 10.4314 /ajcem.v12i3.1

\title{
RISK FACTORS OF CERVICAL INTRAEPITHELIAL LESION IN DOUALA-CAMEROON: IMPLICATIONS OF HERPES SIMPLEX VIRUS TYPE 2, CHLAMYDIA TRACHOMATIS AND TREPONEMA PALLIDUM.
}

1Dongang, N.R.R., ${ }^{\text {1} K o a n g a, ~ M . M . L ., ~}{ }^{1}$ Ngono, N.A.R., ${ }^{2}$ Wankam, M., ${ }^{3}$ Djiakam, N.G., ${ }^{4}$ Djimeli, B., ${ }^{5}$ Fossi, E., ${ }^{5 B}$ Brulet, E.C., ${ }^{6}$ Amvam Zollo, P.H.

\author{
${ }^{1}$ Department of Biochemistry, University of Douala, PO Box 24157 Douala-Cameroun; \\ ${ }^{2}$ Department of Gynaecology, District Hospital of Bonassama, PO Box 12554 Douala- Cameroon; \\ ${ }^{3}$ Department of medical sciences, University of Dschang, PO Box 67 Dschang-Cameroon; \\ ${ }^{4}$ Pathology unit, Laquinitie Douala Hospital PO Box 2701 Douala-Cameroon. \\ ${ }^{5}$ CARESE Laboratory, PO Box 3787 Douala-Cameroon. \\ 'Laboratory of phytobiochemistry, PO Box 812 Yaounde-Cameroon.
}

* Correspondence : Dr KOANGA M.M.L ; Mobile Tel: (+237) 995034 44. E-mail: koanga@yahoo.com

\begin{abstract}
Infection with high risk oncogenic human papillomavirus (HPV) such as HPVs 16 and 18 is the main cause of cervical cancer. The objective of this study was to determine the impact of Chlamydia trachomatis, Herpes simplex virus 2 (HSV 2), Treponema pallidum and some sexual behaviour on malignant progression of cervical lesion in Douala, Cameroon. From July 2009 to January 2010, we performed routine cervical smears to 163 consenting women, who completed a questionnaire on risk factors of cervical cancer. Blood samples were obtained for each of these women and used for the detection of antibodies against Chlamydia trachomatis, HSV 2 and Treponema pallidum. Results obtained showed that 26/163 (17 LSIL and 9 HSIL) of women had abnormal cytology, 75.5\% (123/163) had HSV 2 infection, 19\% (31/163) infected by Chlamydia trachomatis and 4.3\% (7/163) infected by Treponema pallidum. Among the LSIL-positive women 35.3\% (6/17) and $94.1 \%$ (16/17) were infected with Chlamydia trachomatis and HSV 2 respectively. Among those with HSIL cytology, 22.2\% (2/9), 66.7\% (6/9) and 11.1\% (1/9) respectively had Chlamydia trachomatis, HSV 2 and Treponema pallidum. High parity and pregnancy rate was observed among women with positive cytology. Our finding shown high rate of cervical abnormalities among women infected with HSV 2; and among those with a higher number of parities and pregnancies. These results suggest that further investigations should be made in Cameroon to access real burden of these risk factors in the progression and persistence of cervical lesion.
\end{abstract}

Key words: risk factors, cervical cancer, HSV 2, Chlamydia trachomatis, sexually transmitted infections.

\section{INTRODUCTION}

The genital infection by the human papillomavirus (HPV) is a sexually transmitted infection most common, known today as the main cause of cervical cancer in women (1). Epidemiological and molecular investigations have shown that more than 120 different genotypes of this virus have been identified and 40 were recognized as being able to infect the anogenital mucosa (2). Several study are demonstrated that only 18 of these type are considered as high risk oncogenic for the cervix, and 12 (HPVs 16, 18, 31, 33, 35, 39, 45, 51, 52, 56, 58, 59) so as well established, with predominance of HPVs 16 and $18(3,4,5)$. The study of genome organization, regulation of gene expression and protein characterization has allowed understanding the mechanisms of carcinogenesis associated with these viruses $(6,7)$. Their involvement in the malignant transformation of cervix was recognized as serious problem of health in developing countries (8). Many authors' reports that, in most cases, particularly among women under 30 years, HPV infections are transient and only a small percentage of infection persist and may progress to neoplasic cervical lesion. Viral clearance of HPV is quite fast and frequent, on average $70 \%$ of infections regress in 12 months and $90 \%$ in 24 months (9).
The raison of variable period of latency observed in some women remain poorly understood, but it has been generally accepted that other factors contribute to the spread and persistence of precancerous cervical lesion. Among these factors, co-infection with multiple HPV types, viral load, immune deficiency, active smoking, multiparity, multiple sexual partners, early sexual intercourse, excessive use of hormonal contraceptive and other sexually transmitted infections (STI) have been investigated as potentially involved in the transformation of epithelial cells of the cervix. These factors greatly increase likelihood of developing cervical neoplasic lesion (10). Among, STI studied we have infection with Herpes simplex virus type 2 (HSV 2), Chlamydia trachomatis (C. trachomatis) and Treponema pallidum (T. pallidum). These pathogen agents are spread sexually, causing considerable morbidity and socioeconomic problems in several countries. HSV 2 infects the genital mucosa and establishes a life-long infection in sensory ganglia, and it is the most common cause of genital ulcers. Seroepidemiological data from worldwide studies performed during the last decade have estimated the HSV 2 seroprevalence to range from $0 \%$ in children to more than $80 \%$ in selected populations such as STI cohorts in some African countries 
$(11,12)$. Infection with $C$. trachomatis is the most prevalent bacterial STI causing symptomatic and, more commonly, asymptomatic genital infection. In women, C. trachomatis is an important cause of cervicitis and salpingitis as well as pelvic inflammatory disease (13). T. pallidum is the etiologic agent of syphilis. This microorganism is transmitted during sexual activity from a mucocutaneous lesion. In acquired infection, after an initial incubation period of 3 - 90 days, a solitary papule with spirochaetes, erupts at the site of inoculation, which is often found on the genitalia, and less frequently on the rectal mucosa. The fundamental histological changes in acquired syphilis are vasculitis and its consequences, necrosis and fibrosis (14).

The objectives of the present study were to determine the impact of Chlamydia trachomatis, Treponema pallidum and Herpes simplex virus 2 (HSV 2) on the malignant transformation of epithelial cells of cervix and also, to evaluate some behavioural factors involved in the natural history of cervical lesion in Douala, Cameroon.

\section{MATERIALS AND METHODS Study population}

From July 2009 to January 2010, a total of 163 women were enrolled simultaneously in two health centre of Douala (Cameroon). Informed consent was obtained from all women and study was approved by national ethic committee. Women were eligible in the study if they were aged 17 and over, married or unmarried, were not pregnant and not had intercourse 48 hours before. All women were not menstruating and had not made a vaginal washing at time of diagnosis. They completed a structured questionnaire including number of sexual partners, parity, abortion, age of first sexual intercourse and the number of pregnancies.

\section{Sample collection}

During their visit to a gynaecologist, cervical smear was performed for early detection of cervical lesion. Results obtained were classified according to the Bethesda system; as negative, atypical squamous cell of undetermined significance (ASCUS), low squamous cell intraephithelial lesion (LSIL) and high squamous cell intraepithelial lesion (HSIL) (15). All pap smears were analyzed independently by two pathologists and the final result was based on a consensus between of both. Blood sample were obtained by venipuncture and centrifuged at 4000 rpm for $10 \mathrm{~min}$ and serum obtained was store at $30{ }^{\circ} \mathrm{C}$ for detection of antibodies against Chlamydia trachomatis, HSV 2 and Treponema pallidum. Detection of Chlamydia trachomatis, HSV 2 and
Treponema Pallidum

C. trachomatis IgG Enzyme-linked immunosorbent assay (ELISA) from DRG Diagnostics laboratory was used for the detection of specific IgG antibodies against $C$. trachomatis. The assay was carried out as described previously by Piura et al., 1985 (16). Immunoglobulin G antibodies to HSV 2 were determined by microtest-plate ELISA kits (Teco Diagnostics Laboratory, reference IGMH2G-96) using the general technical principles. Each sample was analyzed by indirect blocking ELISA protocol (17). The detection of antibodies to T. Pallidum was performed by the method of heamagglutination (18). Commercial Kit TPHA (Treponema pallidum heamagglutination assay) of Biomagrehb laboratory was used for this purpose. All manipulations were performed according to manufacturer's instructions.

\section{Statistical analysis}

Statistical analysis were performed by SPSS 16.0 software using chi squared test and T-student test. Statistical significance was accepted for $\mathrm{P}<0.05$.

\section{RESULTS}

This study investigated the impact of some sexually transmitted infection on cervical abnormalities, in 163 consenting women randomly recruited in two health centre of Douala (Cameroon). Table 1 summarize the incidence of some microbial infectious agents according to the cytology in the total population. The Pap smear results revealed that HSV 2 is the leading infection among women with $62 \%, 9.8 \%$ and $3.7 \%$ for normal, LSIL and HSIL respectively while Chlamydia is the second with $14.1 \%, 3.7 \%$ and $1.2 \%$. T. Pallidum which count for $3.7 \%, 0.0 \%$ and $0.6 \%$ for normal, LSIL and HSIL respectively in women. 
TABLE 1: INCIDENCE OF C. TRACHOMATIS, T. PALLIDUM AND HSV 2 ACCORDING TO THE CYTOLOGY IN TOTAL POPULATION

\begin{tabular}{|c|c|c|c|c|c|c|c|}
\hline \multirow{2}{*}{ Cytology } & \multicolumn{2}{|l|}{ Normal } & \multicolumn{2}{|c|}{ LSIL a $^{a}$} & \multicolumn{2}{|c|}{ HSIL $^{b}$} & \multirow{2}{*}{ Total } \\
\hline & [n/163] & $(\%)$ & [n/163] & $(\%)$ & [n/163] & $(\%)$ & \\
\hline \multicolumn{8}{|l|}{ HSV 2} \\
\hline Positive & $101 / 163$ & (62) & $16 / 163$ & (9.8) & $6 / 163$ & (3.7) & $123 / 163(75.5)$ \\
\hline Négative & $36 / 163$ & (22.1) & $1 / 163$ & (0.6) & $3 / 163$ & (1.8) & $40 / 163(24.5)$ \\
\hline \multicolumn{8}{|l|}{ C. trachomatis } \\
\hline Positive & $23 / 163$ & (14.1) & $6 / 163$ & (3.7) & $2 / 163$ & (1.2) & $31 / 163$ (19) \\
\hline Négative & $114 / 163$ & (69.9) & $11 / 163$ & (6.7) & $7 / 163$ & (4.3) & $132 / 163(81)$ \\
\hline \multicolumn{8}{|l|}{ T. pallidum } \\
\hline Positive & $6 / 163$ & (3.7) & $0 / 163$ & $(0.0)$ & $1 / 163$ & $(0.6)$ & 7/163 (4.3) \\
\hline Négative & $131 / 163$ & $(80.4)$ & $17 / 163$ & (10.4) & $8 / 163$ & (4.9) & $156 / 163(95.7)$ \\
\hline Total & $137 / 163$ & (84.1) & $17 / 163$ & (10.4) & $9 / 163$ & (5.5) & $163 / 163(100)$ \\
\hline
\end{tabular}

(\%): frequency, a: Low squamous cell intraepithelial lesion b: High squamous cell intraepithelial lesion

Table 2 presents the frequencies of $C$. trachomatis, $T$. pallidum and HSV 2 in women with positive cytology. The data shown that cervical abnormalities are high in women infected with HSV 2: $94.1 \%$ and $66.7 \%$ for LSIL and HSIL respectively (vs $5.9 \%$ and $33.3 \%$ for LSIL and HSIL in women not infected). Significant difference was found between HSV 2 positive and negative cases compared with chi squared test $(\mathrm{P}=0,018)$. $C$. trachomatis was diagnosed in fewer percentages among positive women: 35.3 and 22.2 for LSIL and HSIL respectively and T. pallidum was detected in very low percentage positive women. The difference between negative and positive women is not significant for these two infectious agents.

\section{TABLE 2: FREQUENCY OF C. TRACHOMATIS, T. PALLIDUM AND HSV 2 IN WOMEN WITH POSITIVE} CYTOLOGY

\begin{tabular}{|c|c|c|c|c|c|}
\hline \multirow[b]{2}{*}{ Infections } & \multicolumn{2}{|c|}{$\operatorname{LSIL}^{\text {a }}(\mathrm{N}=17)$} & \multicolumn{2}{|c|}{ HSIL $^{b}(\mathrm{~N}=9)$} & \multirow{2}{*}{ P-value } \\
\hline & [n/17] & $(\%)$ & [n/9] & $(\%)$ & \\
\hline $\begin{array}{l}\text { C. trachmatis } \\
\qquad \text { Positive } \\
\text { Négative }\end{array}$ & $\begin{array}{l}6 / 17 \\
11 / 17\end{array}$ & $\begin{array}{l}(35.3) \\
(64.7)\end{array}$ & $\begin{array}{l}2 / 9 \\
7 / 9\end{array}$ & $\begin{array}{l}(22.2) \\
(77.8)\end{array}$ & 0.134 NS \\
\hline $\begin{array}{ll}\text { HSV } 2 & \\
\text { Négative } & \text { Positive }\end{array}$ & $\begin{array}{l}16 / 17 \\
1 / 17\end{array}$ & $\begin{array}{c}(94.1) \\
(5.9)\end{array}$ & $\begin{array}{l}6 / 9 \\
3 / 9\end{array}$ & $\begin{array}{l}(66.7) \\
(33.3)\end{array}$ & 0.018 * \\
\hline $\begin{array}{l}\text { T. pallidum } \\
\text { Positive } \\
\text { Négative }\end{array}$ & $\begin{array}{l}0 / 17 \\
17 / 17\end{array}$ & $\begin{array}{r}(0.0) \\
(\mathbf{1 0 0 )}\end{array}$ & $\begin{array}{l}1 / 9 \\
8 / 9\end{array}$ & $\begin{array}{l}(11.1) \\
(88.9)\end{array}$ & $0.161^{N S}$ \\
\hline
\end{tabular}

$(\%)$ : Frequency, *: statistical difference, ${ }^{N}$ : No significant difference, N: Total number. ${ }^{\text {a: }}$ Low squamous cell intraepithelial lesion, b: High squamous cell intraepithelial lesion.

Table 3 represents variations of type G immunoglobulin of HSV 2 and Chlamydia in patients with abnormal cytology. We note that this index believes with severity of disease for C. trachomatis: $0.6 \pm 0.2$ to $1.0 \pm 0.2$ respectively for LSIL and HSIL while it decreases for HSV $2(4.4 \pm 0.9$ to $1.3 \pm 0.2)$. The difference between LSIL and HSIL positive patients was statistically significant for HSV 2 compared with $\mathrm{T}$-student test $(\mathrm{P}=0.003)$. 

TABLE 3: VARIATION OF IMMUNOGLOBULIN G ANTIBODIES AGAINST HSV 2 AND $C$.
TRACHOMATIS AMONG WOMEN WITH CERVICAL ABNORMALITIES

\begin{tabular}{|c|c|c|c|}
\hline & $\operatorname{LSIL}^{a}(\mathrm{~N}=17)$ & HSIL b $^{\text {b }}(\mathrm{N}=9)$ & T-student test (P-value) \\
\hline & Mean \pm SE & Mean \pm SE & \\
\hline \multicolumn{4}{|l|}{ Infections } \\
\hline Chlamydia T. & $0.6 \pm 0.2$ & $1.0 \pm 0.2$ & 0.092 NS \\
\hline HSV 2 & $4.4 \pm 0.9$ & $1.3 \pm 0.2$ & $0.003^{*}$ \\
\hline
\end{tabular}

SE = Standard Error, NS: No statistical difference, ${ }^{*}$ : Statistical difference, N: Total number, a: Low squamous cell intraepithelial lesion, b: High squamous cell intraepithelial lesion.

Table 4 examines some risk factors that might involve in development of cervical lesion. The results revealed the higher percentage of cervical lesion in women aged $\leq 17$ years old at first vaginal sex intercourse $(64.7 \%$ and $55.6 \%$ for LSIL and HSIL respectively) compared to women aged $>17$ years old. No statistical difference was found for this factor between these two groups positive women. Regarding parity and pregnancy, we found a high rate of cervical abnormalities in women with a number of parity and pregnancy less than 3 and between 4 and 7: $82.4 \%$ and $66.7 \%$ for LSIL and HSIL for parity and $64.7 \%$ and $66.7 \%$ for pregnancy respectively. Significant statistical difference $(\mathrm{P}<0.05)$ was observed in correlation with cervical abnormalities for these two factors

TABLE 4: INCIDENCE OF SOME RISK FACTORS IN ACCORDING TO THE CYTOLOGY IN WOMEN WITH CERVICAL ABNORMALITIES.

\begin{tabular}{|c|c|c|c|c|c|}
\hline \multirow[b]{3}{*}{ Factors } & \multicolumn{2}{|c|}{ LSIL a $^{a}(\mathrm{~N}=17)$} & \multicolumn{2}{|c|}{ HSIL $^{\mathrm{b}}(\mathrm{N}=9)$} & \multirow{2}{*}{$\chi^{2}$ trend $(\mathrm{P}-$ value $)$} \\
\hline & {$[\mathrm{n} / \mathbf{1 7}]$} & $(\%)$ & {$[\mathrm{n} / 9]$} & $(\%)$ & \\
\hline & & & & & \\
\hline AFVS C (years) & & & & & 0.655 NS \\
\hline$\leq 17$ & $11 / 17$ & $(64.7)$ & $5 / 9$ & $(55.6)$ & \\
\hline$>17$ & $6 / 17$ & (35.3) & $4 / 9$ & $(44.4)$ & \\
\hline Parity & & & & & $0.003 *$ \\
\hline$\leq 3$ & $14 / 17$ & (82.4) & $2 / 9$ & $(22.2)$ & \\
\hline $4-7$ & $3 / 17$ & (17.6) & $6 / 9$ & (66.7) & \\
\hline$\geq 8$ & 0/17 & $(0.0)$ & $1 / 9$ & (11.1) & \\
\hline Pregnancy & & & & & $0.047 *$ \\
\hline$\leq 3$ & $6 / 17$ & $(35.3)$ & $1 / 9$ & (11.1) & \\
\hline $4-7$ & $11 / 17$ & (64.7) & $6 / 9$ & (66.7) & \\
\hline$\geq 8$ & $0 / 17$ & $(0.0)$ & $2 / 9$ & $(22.2)$ & \\
\hline Abortion & & & & & $0.215 \mathrm{NS}$ \\
\hline 0 & $3 / 17$ & 17.6 & $4 / 9$ & 44.4 & \\
\hline $1-2$ & $11 / 17$ & 64.7 & $4 / 9$ & 44.4 & \\
\hline$>2$ & $3 / 17$ & 17.6 & $1 / 9$ & 11.1 & \\
\hline
\end{tabular}

(\%): Frequency, Ns: No statistical difference, *: Statistical difference, N: Total number, a: Low squamous cell intraepithelial lesion, b: High squamous cell intraepithelial lesion, C: Age at first vaginal sex.

\section{DISCUSSION}

The persistent infection with a high-risk HPV is recognized as the principal factor for malignant progression of cervical lesion. However in some women infected since several years, there are no complications while others develop cancer. This finding suggests that other factors play an important role in the transformation process. The aim of our study was to investigate the role played by some sexually transmitted infection on the development of cervical lesion. Our results showed that HSV 2 positive patients are a higher risk of developing cervical lesion. Positive variation of index of immunoglobulin G antibodies against HSV 2 was found among women with cervical abnormalities. Similar results were reported in studies carried out in others sites $(19,20,21)$. This observation reveals the role played by HSV 2 
infection in the persistence and the development of cervical neoplasia. Our knowledge about the specific role of this pathogen agent in the development of cervical lesion is limited. There are several mechanisms by which HSV 2 may act, such as direct genotoxicity. The most likely biologic mechanism is the induction of cervical inflammation leading genotoxic damage through oxidative metabolites (22). Several studies have reported that the carcinogenic molecules (nitric oxide for instance) produced during the inflammatory response induced by this infection, ulcerative lesions of the infection, decrease of local immunity could explain the persistence of cervical lesion related to HPV infection and therefore the loss of viral clearance in patients $(23,24)$. HSV 2 infection increase susceptibility to HPV causing alterations of epithelial cells, thus facilitating the entry of HPV virions.

In our study, no significant correlation was found between cervical abnormalities, $C$. trachomatis and $T$. pallidum. The frequencies of antibodies against $C$. trachomatis and anti-T. pallidum are not high among women having cervical disease. Some previous epidemiological studies have produced the same results regarding association between cervical intraepithelial neoplasia and these two microbial infectious agents. However, others studies reported a positive association between $C$. trachomatis, $T$. pallidum and cervical lesion associated with HPV $(25,26)$. Therefore, the effective role of these pathogens agents remain to be clarified.

\section{REFERENCES}

1. Bosch FX, Nubia M. The viral etiology of cervical cancer. Virus res 2002; 89:183-189.

2. Barzon C, Giorgi C, Buonaguro FM, Palu' G. Guidelines of the Italian society for virology on HPV testing and vaccination for cervical cancer prevention. Infectious Agents and cancer 2008; 3:14.

3. Benjamin GE, Ma paz NB, Sonsoles R, Luis Fernando SS. et al. Genotype distribution of cervical human papillomavirus DNA in women with cervical lesions in bioko, Equatorial Guinea. Diagnostic pathology 2009; 4(31):1-8.

4. Iztel E, Macias C, Villa L, Prado JC. et al. Worldwide genomic diversity of the high-risk human papillomavirus type 31, 35, 52 and 58, four close relatives of human papillomavirus type 16. Journal of virology 2005; 79(21):13630-13640.

5. Olida M, Silvia de Sanjose, Quint W, Bosch XF. et al. Human Papillomavirus type distribution in invasive cervical cancer in Uganda. BMC infectious diseases 2008; 8:85.

6. Mougin $\mathrm{CH}$, Bernard B, Lab M. Biology of papillomavirus infections: General caracteristics. Annals of Clinical Biochemistry 1997; 55(6):555-63.

7. Zur hausen H. Papillomaviruses Causing Cancer: Evasion from Host-Cell Control in Early Events in Carcinogenesis. Journal of the national cancer institute 2000; 92(9):690-695.
In the same context, our data showed positive association between multiple parities, pregnancies and the increased risk of cervical intraepithelial lesion. These results agree with others epidemiological studies relating to association between these risk factors and malignant progression of cervical lesion. Biochemical mechanisms for demonstrating the association between these factors and natural history of cervical lesion is not documented and remain poorly understood today. But, some authors suggest that hormonal change and traumatic producing during pregnancy and childbirth may explain the involvement of these factors in the development of cervical abnormalities $(27,28)$.

\section{CONCLUSION}

The results obtained of this study suggest that HSV 2 infection might increase risk of cervical intraepithelial lesion in our population. Multiple parities and pregnancies are also considerable factors involved in the development and progression of cervical abnormalities. Our data confirm and stress that the screening of cervical abnormalities are desirable for women who attending public and private health centre in Douala (Cameroon), to assess the future risks of cervical intraepithelial lesion and cervical cancer. More investigations should be made about of these risk factors to clarify their real impact in the progression of cervical lesion.

8. Ly A. Cancer of the cervix: News vaccines, News perspectives? Afr J Cancer 2009; 1:65-67.

9. Duport N. Epidemiological data on cervical cancer the state of knowledge - updating 2008; 11-14.

10. Castellsague X, Mireia D, Silvia DS, Nubia M. et al. Worldwide Human Papillomavirus etiology of cervical adenocarcinoma and its cofactors: Implication for screening and prevention. Journal of the National Cancer Institute 2006; 98(5):303-313.

11. Smith JS, Robinson NJ. Age specific prevalence of infection with herpes simplex virus type 2 and 1 : global review. J infect dis 2002; 186:3-28.

12. Gorander S, Mbwana J, Lyamnya E, Lagergard T. et al. Mature glycoprotein G presents high performance in diagnosing herpes simplex virus type 2 infection in sera of different Tanzania cohort. Clin Vaccine Immunol 2006; 13:633-639.

13. Gray-swain MR, Peipert JF. Pelvic inflammatory disease in adolescents. Curr opin obster gynecol 2006; 18:503-510.

14. Mehmet G, William JL. Syphilis in pregnancy. Sex Transm Inf 2000; 76:73-79.

15. Solomon D. The Bethesda system for reporting cervical/vaginal cytologic diagnosis: overview. Int J Gynecol pathol 1991; 10:323-325.

16. Piura B, Sarov B, Kleinman D, Chaim W. et al. Serum IgG and IgA antibodies specific for Chlamydia trachomatis in salpingitis patients as determinded by 
the immunoperoxydase assay. Eur. J. Epidemiol 1985; 1:110-116.

17. Vertergaard BF, Grauballe PC. ELISA for herpes simplex virus (HSV) type specific antibodies in human sera using type heterologous rabbit antibodies. Acta Pathol Microbiol Immunol Scand 1979; 87:261-263.

18. Tomizawa T, Kasamaton S, Yamada S. The usefulness of the heamagglutination test using $T$. pallidum as antigen for serodignosis. Jpn J Med sci bio $1969 ; 22: 341-345$.

19. Clinton J. Cervical cancer: is herpes simplex virus type II a cofactor? Clin Microbiol Rev 1995; 8(4):549-556.

20. Finan RR, Musharrafieh U, Almawi. Detection of Chlamydia trachomatis and herpes simplex virus type 1 or 2 in samples in human papillomavirus (HPV) positive and (HPV) - negative women. Clinical Microbiology and infection 2006; 12(9):918-940.

21. Smith JS, Herrero R, Bosetti C, Munoz N. et al. Herpes simplex virus-2 as a human papillomavirus cofactor in the etiology of invasive cervical cancer. Journal of the national cancer institute 2002; 94(21):1604-1613.

22. Szostek S, Zawilinska B, Kopec J, Kosz-vnenchak M. Herpesviruses as possible cofactors in HPV-16related oncogenesis. Actu Biochimica Polonica 2009; 56(2):337-342.
23. Gorander S, Lagergard T, Malgorzata R, Viscidi RP. et al. Seroprevalence of herpes simplex virus type 2, five oncogenic human papillomavirus and Chlamydia trachomatis in Katowice, poland. Clin Vaccine Immunol 2008; 15(4):675-680.

24. Yu-yen Y, Lim-who K, Ju-hsin T, Chung-hung T. et al. Correlation of viral factors with cervical cancer in Taiwan. J Microbial Immunol Infect 2004; 37:282-287.

25. Gnaoui N, Benchakroun N, Benider A, Hassar M. et al. Typing of human papillomavirus and evaluation of risks factors associated with cervical cancer in morocco. European journal of scientific research 2009; 31(2):229-236.

26. Verteramo R, Pierangeli A, Mancini E, Calzolari E. et al. Human papillomaviruses and genital coinfection in gynaecological outpatients. BMC infectious desease 2009; 9:16.

27. Castellsague $X$, Nubia M. Cofactors in papillomvirus carcinogenesis-role of parity, oral contraceptives, and tobacco smoking. Journal of National Cancer Institute 2003; 31:20-28.

28. Moscicki AB, Hills N, Shiboski S, Powell K. et al. Risks for incident human papillomavirus infection and low grade squamous intraepithelial lesion development in young females. JAMA 2001; 285:2995-3002. 